Локайчук, Світлана. «Образ вітру в мовотворчості Богдана-Ігоря Антонича». Лінгвостилістичні студії, вип. 13, 2020, с. 93-102.

Lokaichuk, Svitlana. "The Image of Wind in the Linguistic Creativity of Bohdan-Ihor Antonych". Linguostylistic Studies, iss. 13, 2020, pp. 93-102.

УДК 811.161.2:821.161.2'06.08.Антонич

https://doi.org/10.29038/2413-0923-2020-13-93-102

\title{
ОБРАЗ ВІТРУ В МОВОТВОРЧОСТІ БОГДАНА-ІГОРЯ АНТОНИЧА
}

\author{
Світлана Локайчук \\ Волинський національний університет імені Лесі Українки, \\ Луцьк, Україна
}

У статті виокремлено та проаналізовано мовні засоби творення образу вітру, який широко представлений у поезіях Б.-І. Антонича З'ясовано, що опорна лексема вітер у мовотворчості поета зазнає багатопланових та багатоманітних образних ускладнень й емоційно-експресивних зрушень. В аналізованих поезіях образ вітру амбівалентний: він $\epsilon$ символом і жаги життя, молодого завзяття, і перешкод, протистояння. Майстерно використовуючи художній прийом персоніфікації, автор перетворив явище природи в ліричного героя, сповненого енергії руху. Образ вітру пов'язаний $з$ асоціаціями, типовими для мови фольклору, і водночас $є$ втіленням індивідуально-авторського бачення світу.

Ключові слова: індивідуальний стиль, контекст, символ, персоніфікація, метафора.

\section{THE IMAGE OF WIND IN THE LINGUISTIC CREATIVITY OF BOHDAN-IHOR ANTONYCH}

\author{
Svitlana Lokaichuk \\ Lesya Ukrainka Volyn National University, Lutsk, Ukraine
}

The article analyzes the linguistic means of creating the image of wind in the poems by B-I.Antonych and argues that the poet's vision of this image is a unique combination of the traditional and modern. The poet's worldview is holistic by nature, and accordingly, all the elements in his works are closely interrelated and, at the same time, contradicting each other. The vivid and metaphorical language of his poetry reflects the philosophical, literary, artistic, and linguistic trends of the first decades of the XX century.

The core lexeme wind in the poet's linguistic creativity acquires new multifaceted figurative meanings and emotionally expressive shifts. The image of wind is correlated with the established symbolic and metaphorical associations: wind - spring - youth, wind - the energy of movement - unreserve, wind - space - freedom. The image of wind is also characterized by ambivalence. It is a symbol of thirst for life and young ardor, and, simultaneously, a symbol of obstacles and confrontation.

The use of metaphorical transferences, based on various associations, allowed the poet to transform the phenomenon of nature into a lyrical hero, full of energy of movement. Most often, the author uses the metaphor of music - the wind, which is motivated by his perception

(C) Локайчук С., Волинський національний університет імені Лесі Українки, 2020.

Це стаття відкритого доступу на умовах СC BY-NC 4.0 
of nature as continuous music of existence. In general, movement and sound are dominant in the structure of this image.

With the help of metaphors, the author created a sensory image of wind, having involved acoustic, visual, tactile, and olfactory image-perceptions. The study has revealed that the metaphorical model of man $\rightarrow$ wind extends to the following areas of associations: man as a social being, age differentiation, appearance and character traits, and the actualization of a gender. The verbalized image of wind comprises the associations typical of the language of folklore, and, alongside, it is the embodiment of the poet's individual vision of the world. It is a particular unity in which the tradition and innovation interact, which directly affects the content of symbols and metaphors.

Key words: individual style, context, symbol, metaphor, personification.

Вступ. Поезія Б.-І. Антонича цікава феноменальним поєднанням традиційного й модерного. Авторові притаманний цілісний світогляд, $\mathrm{y}$ якому всі елементи тісно пов'язані між собою і водночас протиставлені один одному. Яскрава метафорична мова поетичного світу самобутнього українського письменника відбиває не тільки філософські, літературномистецькі, але й мовні шукання перших десятиліть XX століття та «як органічна частина словника української мови засвідчує специфіку нової поетичної свідомості» (Павличко, Перстень 8).

Різні аспекти індивідуального мовного стилю поета були вже об'єктом досліджень мовознавців. $€$ чимало влучних визначень особливостей його лінгвопоетики, для якої характерна яскрава та оригінальна метафоричність. Природу словесної образності Б.-І. Антонича досліджували А. Бондаренко, І. Дмитрів, І.Даниленко, М. Ільницький, О. Маленицька, У. Матвійчук, Л. Стефановська, Н. Якубчак та інші.

Мета роботи - проаналізувати мовні засоби творення образу вітру в поезіях Б.-І. Антонича, декодувати його змістове наповнення в контексті індивідуально-авторської та національно-мовної картин світу.

Матеріал і методи дослідження. Словесний образ вітру в поезіях Б.-І. Антонича схарактеризовано із залученням відповідних методів i прийомів дослідження, серед яких основним є метод лінгвостилістичного спостереження. Метод концептуального аналізу застосовано для з'ясування впливу контексту на семантику слова-символу вітер, а також для відтворення мовної особистості автора. Прийом лінгвістичного моделювання необхідний для реконструкції напрямів метафоричних перенесень. Уточнення плану змісту окремих слів здійснювалося 3 використанням лексико-семантичного аналізу.

Результати дослідження та дискусія. Мовний образ дослідники схильні розглядати як поєднання фрагментів індивідуально-авторської та національно-мовної картини світу. О. Черевченко трактує образотворення через інтерпретацію світу митцем, зазначаючи, що образ $є$ «результатом особливого (художньо-суб'єктивного) пізнання дійсності, яке базується, 3 одного боку, на притаманній носіям певної етнолінгвокультури системі асоціативно-смислових зв'язків з їі загальнолюдськими і національно- 
специфічними елементами, а з другого, - характеризується суб'єктивізацією цих елементів» (26).

У структурі концепту 3. Попова важливе місце відводить образному компоненту. На думку дослідниці, він «складається з двох елементів перцептивного образу i когнітивного (метафоричного) образу, які однаково відображають образні характеристики предмета чи явища, що концептуалізуються» (Попова 109). Складники образу, виділені на основі чуттєвого та метафоричного сприймання, допомагають не лише виокремити його в художньому тексті, але й «осягнути той переносний (а часто і символічний) смисл, який вкладено у мовні одиниці» (Бавус 244).

Лексема вітер є однією з найбільш активних в українській поезії XX ст. Л. Кравець зазначає, що висока частотність метафоризації вітру у віршових текстах початку XX ст. спричинена, по-перше, бурхливими суспільними подіями, по-друге, художньо-естетичними тенденціями тих років (99). Дослідження особливостей структурування цього образу дає можливість визначити ціннісні смислові орієнтири не лише певної епохи, а й окремого митця.

За Словником символів, вітер - конкретне вираження однієї 3 основних стихій світобудови - повітря (інші - Земля, Вода, Вогонь), <...> символ духу, дихання, Всесвіту; невловимості, неусвідомленості; швидкості; якоїсь звістки (як правило, однієї); шкоди, руйнації і водночас оновлення» (Словник символів 27). У поетичній мові Б.-І. Антонича опорна лексема вітер, зафіксована 98 разів, зазнає багатопланових та багатоманітних образних ускладнень. Починаючи з дебютної збірки поета «Привітання життя», образ вітру варіюється в мотивах окремих поезій і циклів.

Н. Якубчак відзначає, що образний ряд зі значенням переміщення, руху, пориву вже в першому вірші та циклі «Зриви і крила» пов’язаний із «мотивом життя як невпинного руху, зростання, поривання, пошуку, що підсилюється мотивом сталості як смерті» (29). У поезії «Пісня про вічну молодість» рвучкий рух, нестримність, жага життя передано поєднанням розмовного дієслова тріснути 'дуже швидко вдарити' (Словник української 10: 275) та інверсованої конструкції вітер буйний:

\section{тріснути батогом на вітер буйний}

і вдаль, і вдаль! (Антонич 41).

Усталений фольклорний вираз вітер буйний фіксуємо і в пізніших поезіях, наприклад, у стилізованій під народну пісню «Коломийці про провесну»:

Вітер віє, вітер буйний, віє за горою,

мороз ходить, мороз бродить під руки з весною (Антонич 69).

Прикметник буйний викликає звичну асоціацію $з$ вітром, проте в поезіях реалізує переносне значення - 'невгамовний, нестримний' (Словник української 1:251). Уважаємо, що поведінкова парадигма персоніфікованого вітру відповідає особистості 3 темпераментом холерика: 
Босоніж буйний вітер біг по броді, ногами топче мокрими стручки (Антонич 49).

Ще один постійний епітет народнопоетичного походження композит буйногривий, який у контексті з епітетами рвучий, юний, молодий виступає символом молодості, невгамовності:

\section{З рвучим вітром буйногривим!}

Бути вічно юним, вічно молодим! (Антонич 42).

За цією моделлю створено й авторський неонім вітер буйновійний:

Хати, немов гриби червоні, ростуть під вітром буйновійним (Антонич 224).

Сильна позиція початку першої збірки Б.-І. Антонича вплинула на те, що в наступних поезіях і циклах образи 3 динамічною семантикою асоціюються 3 «мотивом життя-пориву, прагненням до мети» (Якубчак 28). Вияв енергії, молодого завзяття супроводжується вживанням постійних лінійних сполук весна $i$ вітер, які можуть розгортатися, отримувати різнобічну мотивацію:

Червоні клени й клени срібні, над кленами весна і вітер (Антонич 118).

Мотиви єдності весни і вітру символізують пробудження природи. Потенційна образність лексеми вітер стає основою створення поетичного образу суб'єкта, що змінює параметри світу, визначає перетворення його складників, тому в поезії «Малий гімн» звучить своєрідний авторський маніфест:

Звеличую усоте вітер,

звеличую стокрот весну (Антонич 291).

Паралель природна стихія - творчий неспокій людини, яка прагне пізнати світ, спостерігаємо у циклі «Зриви й крила», де динаміка, інтенсивність руху символізують бажання ліричного героя вирватися за межі сірої дійсності, віднайти себе, що досягнуто використанням метафори шумить у серці вітер (Антонич 59). Градація вітер - буревії відображає наростання змістової ознаки символу вітру як носія креативу, перетворень:

Чи ж не сильніші в грудях буревії, як порожнечі дійсності клятьба?

- Не знали, що гарніший світ від мрії (Антонич 60).

Інколи в поетичній мові переосмислюються, зазнають перекодування фразеологізми. Наприклад, відомий вислів на вітер говорити (кидати слова) 'даремно, марно говорити' (Словник української 1:687) в поезії «На вітер» набуває зовсім іншого значення - це заклик співати пісню суголосно з природою:

Кинь пісню на вітер,

на вітер слова!

Десь шепотом віти, десь шумом трава (Антонич 135). 
В образній системі Б.-І. Антонича важливу роль відіграє поєднання понять вiтру і простору. На наш погляд, можна говорити про складний образ, що виник як наслідок взаємодії природної стихії та просторової безконечності:

Не клич, не клич небачно імені натхнення,

бо ось воно, як вітер, що звільнився з неба

і втік за межі простору у струм заземний (Антонич 202).

Значення простору наявне у семантичній структурі лексем даль 'простір, що видніється вдалині', далеч, далечінь 'далекий простір' (Словник української 2: 209), безкрай 'безмежжя' (Словник української 1: 132), які виступають контекстуальними синонімами до слова простір у поезії «Дороги», а динаміка руху сприймається як абсолютний вияв невичерпності простору:

Тільки безкрай і далеч іскриться,

тільки безвість вітає вітрами (Антонич 137).

У вірші «Пісня про ізгоя» виразником відношень вітер - простір $є$ вживана автором двічі сполука далекий подув, ускладнена введенням додаткових елементів - поле, запах землі:

І лиш подув далекий із піль <...>

Тільки подув далекий приносить

свіжий запах німої землі (Антонич 280).

Традиційну асоціацію вітру з поняттями 'воля', 'свобода' у поезіях Б.-І. Антонича втілено за допомогою дієслова звільнятися 'позбавлятися того, що стискує, зв'язує, обмежує і т. ін. в рухах; вивільнятися' (Словник української 3: 483) та атрибутивом звільнений:

Не клич, не клич небачно імени надхнення,

бо ось воно, як вітер, що звільнився з неба

і втік за межі простору у струм заземний (Антонич 205).

...аж рветься дощ, як втятий посторонок,

і вітер звільнений вирує колом (Антонич 215).

Дії, спричинені природною стихією, часто перебувають у межах стандартного асоціативного поля слова-стимулу: вітер - вiє, шумить, жене, гуде, котить, кружляє, несе. В усталеному вислові вітер віє у різних контекстах втілено неоднакові змістові та експресивні відтінки. У поезії «Вітер століть» віяння вітру має урочисте, радісне, мажорне звучання, яке посилюється використанням епітетів (крилатий, вільний, неспинний) та синонімів (неспинний - нестримний, вільний - свобода):

І вітер віє від століть,

крилатий, вільний і неспинний,

і вчить свободи, туги вчить

за чимсь незнаним і нестримним (Антонич 223).

Двічі вжита інверсія віяли вітри в поєднанні з описом беззоряної ночі страшної ночі страти Христа, символізує тривогу, невідворотність трагедії в поезії «Mater dolorosa (Страдальна мати)» зі збірки «Велика гармонія»: 
В темну, чорну ніч

віяли вітри (Антонич 104).

У мовотворчості Б.-І. Антонича відображено також традиційне уявлення про вітер як символ перешкод: Дорогу нам не стелять тільки рожі, навпроти віє вітер сніговий (Антонич 50), руйнації, заподіяної шкоди. Останнє відображено в предикатах, що містять сему 'руйнувати', імпліцитно наявну в дієсловах зривати, видирати, торсати: Мов черепицю із дахів, / зриває вітер зорі з неба (Антонич 207); Бурхливий вітер видирає сторінки з книжок / і розвіває вчених слів скарби (Антонич 276); вітер торсає хмарами, білою гривою неба (Антонич 71).

Асоціативний зв'язок вітру і виявом ворожнечі, недоброзичливості актуалізовано використанням епітета злий: Злий вітер, що натхненням людську розпач шарпав, / вже тихне (Антонич 234).

За спостереженням В. Білик, зовсім «невелика кількість вихідних мотивів Антоничевої творчості дає нам у кінцевому результаті досить об'ємний ряд образів, причому часто 3 діаметрально протилежним зарядом» (126). Таким чином, образ вітру в аналізованих поезіях амбівалентний: він є символом і жаги життя, енергії, молодого завзяття, i перешкод, протистояння, неприязні.

За особливостями метафоричного вживання лексеми вітер можна визначити ціннісно-смислові орієнтири не тільки окремого митця, а й певної епохи. Л. Кравець звертає увагу на високу частотність метафоризації лексеми вітер у віршових текстах початку XX ст. (99). 3 одного боку, це було спричинено бурхливими суспільними подіями, а 3 іншого - художньо-естетичними тенденціями тих років.

Однією з характерних ознак індивідуального стилю Б.-І. Антонича $є$ насиченість текстів яскравими, самобутніми музичними метафорами. Дослідники творчості письменника називають його композитором у віршах, де слова переходять у звуки, витворюючи мелодію тієї «іншої дійсності», яку поет відкривав для себе все життя. У. Матвійчук зазначає, що кожна збірка поета - це своєрідний оркестр метафор, значення яких розвиваються під акомпанемент певних музичних інструментів. У поезіях Б.-І. Антонича дослідниця нараховувала 17 видів музичних інструментів, серед них духові, струнні, клавішні та ударні (Матвійчук 48).

Для вираження певної ідеї автор залучає образ музичного інструмента відповідно до його музичних властивостей. Наприклад, високі поривання ліричного героя добре передає скрипка - найвищий за регістром інструмент. Образ скрипки знаходимо у всіх поетичних збірках Б.-І. Антонича, за винятком «Книги Лева». Порівняння вітру зі скрипалем (суб'єктом) та смичком (об'єктом) експліковане через назви музичних інструментів чи їх частин - скрипка, струна:

\section{На березовій скрипці вітер грав}

i, наче шовком, витер кожний камінь (Антонич 151).

На березі білі берези напнуті, мов струни 
День вітром по них потягає, неначе смичком (Антонич 70).

Найчастіше метафоричний образ вітру-музиканта поєднано 3 назвами струнних інструментів - скрипки, лютні, ліри:

Вітер торгає листя, мов струни на лютні.

Жовч накипає у серці, аж випаде з меж (Антонич 72).

Міста в дротах - під вітром ліри.

Це тут, де мурів скупість взором,

без сяйва навіть сонце сіре (Антонич 182).

Слово струна поєднується не 3 назвою інструмента, а стає складником метафоричного перенесення гілки, пагони - струни: струни беріз, струни яблуні, струни листя, які торкає вітер, наприклад:

Дме вітер у руна

життя молоде,

на яблуні струнах

долоні кладе (Антонич 135).

У пейзажній ліриці фіксуємо переважно розгорнуті метафори, до складу яких входить кілька метафоризованих компонентів, що поєднують візуальні й акустичні трансформації, як у поезії «Екстатичний восьмистроф»:

Червона сажа заходу вкриває липи,

що круглі, мов решета, сіють сонне сім'я,

і струни листя замовкають наглим схлипом

під вітру дотиком, що тишу шумом вим'яв (Антонич 201).

Наділений від природи музичним слухом і рідкісним баченням світу через музичні образи, поет тонко відчував гармонію всього, що його оточувало. На думку Д. Павличка, секрет оригінальності Б.-І. Антонича в тому, що він «з неймовірною віртуозністю поєднує зорові враження 3 музичними, слуховими, вдаючись до різних способів передачі відчуття кольорів і скульптурних форм образами звукового ряду i, навпаки, відчуття розмаїтих явищ звуку - метафорами зорового походження» (Павличко, Літературознавство 455).

Метафора дозволяє гармонізувати світ авторських уявлень та обмеженість слова. Зокрема, у вірші «Буря» однією, короткою точною фразою змальовано картину буревію, яка асоціюється зі звучанням оркестру: Кларнетів схлип, і вітру помах (Антонич 185). У поезіях останніх років Б.-І.Антонич вносить образ духових інструментів, створюючи метафори вітри трублять (Антонич 221), вітри грають на мідних трубах, вітри - сурмачі (Антонич 236).

Уявлення про вітер як «дихання божества» бере початок зі слов'янської міфології та фольклору (Кравець 96). У поезії «Голос моря» цей міфологічного походження символ поєднується 3 враженнями від шуму розбурханого моря і трансформується в образ Божественної симфонії: 
Безмежна, вічная симфоніє,

В акордах з вітром віддих Бога грає,

3 моїм Його хід серця в змазі б'є (Антонич 287).

За допомогою метафоричних перенесень у поетичних текстах створено сенсорний образ вітру із залученням акустичних, зорових, тактильних, нюхових відчуттів: Заслуханий у дружній вітер, / свій давній голос чую в тиші (Антонич 184); подивлюся на вітер крізь віти (Антонич: 70); 3 долоні вітру, що прощався з нами, грудка / погаслої зорі упала, мов дарунок (Антонич 228); а зимні долоні вітру / що пахне глиною підміських піль / холодять парені виски й біль (Антонич 264); Крилатий вітер $i$ пахучий, / мов дзенькіт сріблених шабель (Антонич 133); Руки кладемо на вітер запашний й віддихаємо глибоко (Антонич 74).

Ще однією особливістю метафор Б.-І. Антонича $є$ їх тісний зв'язок із фольклорними традиціями творення образів, зокрема персоніфікацією, наділенні природних явищ властивостями, притаманними живій істоті. Уособлення вітру досягається поєднанням з дієсловами бігти, топтати, бродити:

Босоніж буйний вітер біг по броді, ногами топче мокрими стручки (Антонич 49).

Це бродить вітер, шуму перший родич, і пальцем стукає до неба віллі (Антонич 67).

Міфологічні уявлення про вітер відбиті в традиції українського поетичного метафоротворення (Кравець 96). Детальне розгортання метафоричної моделі людина $\rightarrow$ вітер у ліриці Б.-І. Антонича відбувається за такими напрямами перенесень: людина як суспільна істота: Заслуханий у дружній вітер, свій давній голос чую в тиші (Антонич 184); вікова диференціація: i вітер юний, $і$ зорі сині (Антонич 296); особливості зовнішності: Ось вітрами дебелими / вже надходить епоха світань (Антонич 153), хрест струнких вітрів (Антонич 190); риси характеру: Приходь, струнка княгине, дзвінко й розсуди мене і вітер! / Нас двох сьогодні забагато. I обидва ми уперті (Антонич 231); гендерні ознаки (вітер - символ чоловічого начала, експлікований у відповідній етикетній ситуації): підніс угору вітер / на привітання дня пилюки бовдур, / немовби капелюх із голови (Антонич 78).

У структурі метафоризованого образу вітер - господар, пастух переважають номінації, пов'язані з реаліями традиційного сільського побуту: Знов котить вітер ночі колесо з узгір'їв лисих (Антонич 212); лиш вітер обертає жорна хмар (Антонич 75); Так загуділи колоски туги, бо вітер за чуби гнуздав луги (Антонич 45); Як диню сония зсуне вітер / на решето ясних долин (Антонич 186); і вітер листя розгортає, бо хоче сонце з вільх зірвати (Антонич 220); як вітер хмари пожене на сон, / немов табун овець до водопою (Антонич 71); Вітри ранкові, наче мітли, / стежок змітають ніч весінню (Антонич 166); Вітер жовтий лист з дерев змітає помелом (Антонич 68). 
Персоніфікація вітру досягається поєднанням із предикатами, що містять сему 'спокій' - заснути, спати: Не тихне клик чайний над лиманами, що в них заснули вітри завмерлих бур, немов стяги потоплених човнів (Антонич 299); Де берег дня, за морем неба, сплять вітри майбутні і наші вірні зорі (Антонич 216).

Образ вітру репрезентований і як асоціація з тваринним світом та $\epsilon$ результатом смислових перетворень, заснованих на символічних конотаціях. Зооморфну метафору кінь - вітер, у якій імпліцитно присутня сема 'нестримна сила, воля', виявлено в поезіях різних років, наприклад:

Твій кінь, мов чорне полум'я, мов вітер спійманий,

лиш гриви молоко спливає шиєю гнучкою...(Антонич 229).

Така метафора у тексті поезії «Знак дуба» увиразнюється поєднанням назви явища природи з дієсловами прив'язати, попутати 'в'язати, стягнути путами ноги коня (передні з однією задньою або тільки передні); стриножити' (Словник української 7: 242):

Прив'язані до пнів, попутані вітри й бог ляку

столиций, хитрий бог,що все нове обличчя має (Антонич 213).

Міфологічне підгрунтя має осмислення вітру як птаха, крилатої істоти: Крило плаща із пліч. Крило вітрів над домом, / вузли димів, що в'яжуть небо з міста колом (Антонич 234); Крилатий вітер, дужий вітер, що зорі, листя й ластівки несе, / сп'яняє серце (Антонич 133).

Зазначимо, що в поетичних текстах Б.-І. Антонича відбувається трансформація фольклорних першооснов і наповнення їх новим, авторським змістом. Фольклорний матеріал поет використовує наче кольорову мозаїку, викладаючи з фольклорних елементів щоразу новий малюнок.

Висновки та перспективи дослідження. Отже, опорна лексема вimep у мовотворчості Б.-І. Антонича зазнає багатопланових та багатоманітних образних ускладнень й емоційно-експресивних зрушень. В аналізованих поезіях образ вітру амбівалентний: він є символом і жаги життя, молодого завзяття, i перешкод, протистояння. Майстерно використовуючи художній прийом персоніфікації, автор перетворив явище природи в ліричного героя, сповненого енергії руху.

Створений поетом образ вітру пов'язаний з асоціаціями, типовими для мови фольклору, і водночас $\epsilon$ втіленням індивідуально-авторського бачення світу. Він становить особливу єдність, у якій взаємодіють традиції і новаторство, що безпосередньо позначається на змістовому наповненні символу і метафор. Домінантними в структурі цього образу є рух і звук

У перспективі, на наш погляд, доцільно зробити лінгвостилістичний аналіз репрезентованих у мовотворчості Б.-І. Антонича образів усіх природних стихій для моделювання поетичної картини світу митця. 


\section{Список використаної літератури}

Антонич, Богдан Ігор. Вибрані твори. Київ: Смолоскип, 2012.

Бавус, Тетяна. «Мовний образ як компонент мовно-національної та індивідуальноавторської картин світу». Вісник Львівського університету. Серія філологічна, вип. 63, 2016, с. 242-6.

Білик, Віра. «Деякі міфологічні образи й мотиви поезії Б.-І. Антонича». Вісник Вісник Львівського університету. Серія філологічна, вип. 27, 1999, с. 126-32.

Кравець, Лариса. «Метафора вітру в українській поезії ХХ століття». Культура слова, вип. 72, 2010, с. 94-100.

Матвійчук, Уляна. «Метафорична акустика творчості Б.-І. Антонича». Держава ma регіони. Серія: Гуманітарні науки, № 1 (48), 2017, с. 48-52.

Павличко, Дмитро. Літературознавство. Критика. У 2 т. Т. 1. Київ: Видавництво Соломії Павличко «Основи», 2007.

Павличко, Дмитро. Перстень життя: літературний портрет Богдана-Ігоря Антонича. Київ, 2003.

Попова, Зинаида, и Стернин, Иосиф. Когнитивная лингвистика. Москва: АСТ: ВостокЗапад, 2007.

Словник символів, уклад. О. І. Потапенко, М. К. Дмитренко, та ін. Київ: Редакція часопису «Народознавство», 1997.

Словник української мови, за ред. І. К. Білодіда. В 11 т. Київ: Наукова думка, 1970-1980.

Черевченко, Олександр. Лінгвістичні аспекти аналізу поетичного тексту: неокласичні виміри. Умань: ВIЗАВI, 2012.

Якубчак, Наталія. «Поетика ліричного циклу Б.-І. Антонича». Наукові записки НаУКМА. Філологічні науки, т. 48, 2005, с. 24-32.

\section{References}

Antonych, Bohdan Ihor. Vybrani tvory. Kyiv: Smoloskyp, 2012.

Bavus, Tetyana. "The Language Image as a Component of the National Language and the Individual Author's Pictures of the World". Visnyk of Lviv University. Series Philology, iss. 63, 2016, pp. 242-6.

Bilyk, Vira. "Some Mythological Types and Motifs in the Poetry of B. I. Antonych". Visnyk of Lviv University. Series Philology, iss. 27, 1999, pp. 126-32.

Kravets, Larysa. "Metafora vitru v ukrainskii poezii XX stolittia". Kultura slova, iss. 72, 2010, pp. 94-100.

Matviychuck, Uliana. "Metaphorical acoustics of B.-I. Antonych's creativity”. State and Regions. Series: Humanitarian Sciences, no. 1 (48), 2017, pp. 48-52.

Pavlychko, Dmytro. Literaturoznavstvo. Krytyka. 2 vols. Vol. 1. Kyiv: Vydavnytstvo Solomii Pavlychko "Osnovy", 2007.

Pavlychko, Dmytro. Persten zhyttia: literaturnyi portret Bohdana-Ihoria Antonycha. Kyiv, 2003. Popova, Zinaida, and Sternin, Iosif. Kognitivnaja lingvistika. Moskva: AST: Vostok-Zapad, 2007.

Slovnyk symvoliv, edited by O. I. Potapenko, M. K. Dmytrenko, and all. Kyiv: Redaktsiia chasopysu "Harodoznavstvo", 1997.

Slovnyk ukrainskoi movy, edited by I. K. Bilodid. 11 vols. Kyiv: Naukova dumka, 1970-1980.

Cherevchenko, Oleksandr. Linhvistychni aspekty analizu poetychnoho tekstu: neoklasychni vymiry. Uman: VIZAVI, 2012.

Yakubchak, Natalia. "The Poetics of B.-I. Antonych's Lyrical Cycle”. NaUKMA Research Papers. Linguistics, vol. 48, 2005, pp. 24-32. 